\title{
The influence of urban heat islands and socioeconomic factors on the spatial distribution of Aedes aegypti larval habitats
}

\author{
Thiago S. de Azevedo, ${ }^{1}$ Brian Patrick Bourke, ${ }^{1}$ Rafael Piovezan, ${ }^{2}$ Maria Anice M. Sallum ${ }^{1}$ \\ ${ }^{1}$ Department of Epidemiology, Faculty of Public Health, University of São Paulo; ${ }^{2}$ Department of Zoology, \\ São Paulo State University (Unesp), Rio Claro, São Paulo, Brazil
}

\begin{abstract}
We addressed the potential associations among the temporal and spatial distribution of larval habitats of Aedes (Stegomyia) aegypti, the presence of urban heat islands and socioeconomic factors. Data on larval habitats were collected in Santa Bárbara d'Oeste, São Paulo, Brazil, from 2004 to 2006, and spatial and temporal variations were analysed using a wavelet-based approach. We quantified urban heat islands by calculating surface temperatures using the results of wavelet analyses and grey level transformation from Thematic Mapper images (Landsat 5). Ae. aegypti larval habitats were geo-referenced corresponding to the wavelet analyses to test the potential association between geographical distribution of habitats and surface temperature. In an inhomogeneous spatial point process, we estimated the frequency of occurrence of larval habitats in relation to temperature. The São
\end{abstract}

Correspondence: Thiago S. de Azevedo, Department of Epidemiology, Faculty of Public Health, University of São Paulo, Avenida Doutor Arnaldo 715, CEP 01246904, São Paulo, SP, Brazil.

Tel.: +55.11.3061.7951.

E-mail: azevedots@gmail.com

Key words: Aedes aegypti; Urban heat island; Spatial analysis; Wavelets; Social Vulnerability Index; Brazil.

Contributions: TSA, MAMS conceived the idea; TSA did all analyses; RP collected the mosquito data; TSA, RP, MAMS, BPB wrote the paper.

Conflict of interest: the authors declare no potential conflict of interest.

Funding: MAMS received financial support from FAPESP (Grant 2014/26229-7), and CNPq Grant no. 301877/2016-5; TSA was a beneficiary of a CNPq post-doctorate grant no. 402054/2014-8.

Received for publication: 5 September 2017.

Revision received: 21 January 2018.

Accepted for publication: 22 January 2018.

(C) Copyright T.S. de Azevedo et al., 2018

Licensee PAGEPress, Italy

Geospatial Health 2018; 13:623

doi:10.4081/gh.2018.623

This article is distributed under the terms of the Creative Commons Attribution Noncommercial License (CC BY-NC 4.0) which permits any noncommercial use, distribution, and reproduction in any medium, provided the original author(s) and source are credited.
Paulo State Social Vulnerability Index in the municipality of Santa Barbára d'Oeste was used to test the potential association between presence of larval habitats and social vulnerability. We found abundant Ae. aegypti larval habitats in areas of higher surface temperature and social vulnerability and fewer larval habitats in areas with lower surface temperature and social vulnerability.

\section{Introduction}

Intensive urbanisation since the 1950s has altered the natural landscape in Brazil and severely impacted communities of plants and animals in these areas (McKinney, 2008; Knapp et al., 2017). Urbanisation has generally been most severe in economically deprived areas and is frequently accompanied by poor urban planning and reduced levels of sustainability (Haughter and Hunter, 1994). The resulting changes of the environment can create ecological conditions that, coincidentally, favour the presence of mosquito vectors of human pathogens and thus the establishment of epidemics of vector-borne diseases (Lafferty, 2009; Misslin et al., 2016). Among the mosquito vectors most strongly associated with urban environments is Aedes (Stegomyia) aegypti (Linnaeus, 1762) (Foratini, 2002), which plays a key role in the transmission of dengue and yellow fever viruses (Foratini, 2002; Jentes et al., 2011; Simmons et al., 2012), chikungunya virus (Leparc-Goffart et al., 2014; Vega-Rúa et al., 2014) and zika virus (Freitas et al., 2015; Zanluca et al., 2015). Consequently, the Brazilian public health system has been continuously challenged by the risk of arboviruses, particularly dengue (Braga and Valle, 2007; Barcellos and Lowe, 2014) and, more recently, zika (Faria et al., 2017), chikungunya (Cardoso et al., 2017) and urban yellow fever (Possas et al., 2018) epidemics.

Ae. aegypti was reintroduced into Brazil in the 1970s, after being previously eradicated in the 1950s (Araújo et al., 2015). The species has since colonised most of the country, facilitated by intensive commerce, urbanisation, social vulnerabilities and human migration (Gubler, 1998; Chang et al., 2014) making this species a major public health threat (Guzman and Harris, 2015). Urban environments are a particularly important habitat for $A e$. aegypti, as they provide an abundance of suitable containers for larval development, such as plates, plant pots, cans, bottles, recyclable containers and swimming pools (Piovezan et al., 2012; Kraemer et al., 2015). Ae. aegypti is also strongly associated with poor sanitary conditions and lack of waste residual recycling typical of rapidly expanding urban areas and seen as important contributory factors to epidemics of vector-borne diseases (Costa et al., 2017).

The fact that mosquitoes are insects, and therefore exothermic, makes temperature a fundamentally important factor in the 
dynamics of transmission of vector-borne diseases (Meineke et al., 2013; Xu et al., 2017). This kind of transmission dynamics is highly dependent on temperature because the latter not only affects mosquito survivorship and the duration of its life cycle but also the extrinsic incubation period of the pathogen (Yang et al., 2009; Bhatt et al., 2013; Naish et al., 2014). For example, temperatures above $30{ }^{\circ} \mathrm{C}$ can reduce the extrinsic replication cycle of the dengue virus from 12 to 7 days and alter infection rates from 67 to 95\% (Watts et al., 1987). A particularly important phenomenon that affects temperatures in urban environments is the concept known as urban heat island (UHI). An UHI increases surface temperature in urban areas relative to the surrounding countryside and impacts human wellbeing and public health negatively (Mohajerani et al., 2017). Urbanisation and the intensive use of man-made materials significantly increases anthropogenic heat production, interfering with wind dynamics, physical and thermal properties of heat absorption and heat dissipation (Landsberg, 1981; Oke, 1995). This urban climate is characterised by temperatures that can be 1 or $2{ }^{\circ} \mathrm{C}$ higher than the surrounding countryside and may in some cases be $3{ }^{\circ} \mathrm{C}$ higher (Tyson et al., 1972) as frequently occurs in metropolitan areas. These variations in the surface temperatures brought about by UHIs can favour the occurrence of vector-borne disease epidemics (Misslin et al., 2016), including Brazil's dengue epidemics (Araujo et al., 2015).

The current study aims to establish the spatial distribution of Ae. aegypti and explore the potential associations among vector larval habitat frequency, UHIs and the social vulnerability index in the city of Santa Barbara d'Oeste, Sao Paulo, Brazil. The study should provide a greater understanding of social vulnerability index and weather factors associated with the occurrence of $A e$. aegypti larval habitats and the potential risk of arbovirus exposure in the urban environment. It should also assist dengue surveillance programmes in the development of more effective public health and urban development strategies.

\section{Materials and Methods}

\section{Sampling area}

The sampling area is located in the Santa Bárbara d'Oeste municipality, in the Atlantic Forest biome, between the geographical coordinates $22^{\circ} 44^{\prime} 09^{\prime \prime}$ - 22 $2^{\circ} 51^{\prime} 43$ " South and 47²0'27" 47 $30^{\prime} 36^{\prime}$ "West (Figure 1). Its total area covers $271 \mathrm{~km}^{2}$ and its population is estimated at 190,769 inhabitants by Fundação Sistema Estadual de Dados (SEADE), a non-profit Governmentrelated organization that collects, organizes and processes data on population, education, health, finance for the State of Sao Paulo (SEADE, 2010). The study area has an undulating terrain, and its climate, according to Centro de Pesquisas Meteorológicas e Climáticas Aplicadas à Agricultura (CEPAGRI) is characterised by dry winters with moderate temperatures and wet summers with moderately high temperatures (CEPAGRI, 2013).

\section{Field collections}

In the present study, we used data collected by the Zoonoses Control Center of the Municipal Health Department of the Municipality of Santa Bárbara d'Oeste (SP). Field collections in the urban area were carried out daily from February 2004 to February 2006. During the period, we estimated that more than
300,000 houses were inspected, resulting in the collection of 1,891 mosquito larvae (Piovezan et al., 2012).

\section{Mosquito identification and data base}

Larvae were identified using the morphological key introduced by Forattini (2002). The information was stored in a hierarchically organised database by larval habitat type (1-tire; 2 - plant pot and drip tray; 3- tin, jar, bottle; 4- bucket, washtub, barrel; 5- water tank; 6- bottle; 7- other removable container; and 8- other nonremovable container), collection date and the geographical coordinates of the site of collection.

\section{Spatial analysis}

The periodicity and seasonality of larval habitats were defined based on the protocols proposed by Cazelles et al. (2007), Nagao and Koelle (2008), Johansson et al. (2009), Chowell et al. (2011), Cuong et al. (2011) and Thai and Anders (2011) using wavelets $f(\mathrm{t})$ statistics (Weng and Lau, 1994; Daubechies, 1988), expressed by:

$\omega_{l, t^{\prime}}(f)=\int f(t) \Psi_{l, t^{\prime}}^{*}(t) d t$

where $l$ is the parameter of dilation, $t^{\prime}$ is the parameter of translation, and * the conjugated complex of the wavelets $\Psi l, t$ '.

$\Psi_{l, t^{\prime}}(l)=\frac{1}{\sqrt{l}} \Psi\left(\frac{t-t^{\prime}}{l}\right)$

$\Psi(t)$ is the mother wavelet, and the transformation of the wavelet is expressed by:

$f(t)=\frac{1}{C_{\Psi}} \iint W_{\left(l . t^{\prime}\right)}(f) \Psi_{l, t^{\prime}}(t) d t^{\prime} \frac{d l}{l^{2}}$

$C_{\Psi}$ is a normalization factor expressed by:

$C_{\Psi}=2 \pi \int_{0}^{\infty} \frac{|\psi(\omega)|^{2}}{\omega} d \omega<\infty$

The non-stationary signals of larval habitats were addressed through breakdown of the temporal series and frequency to verify

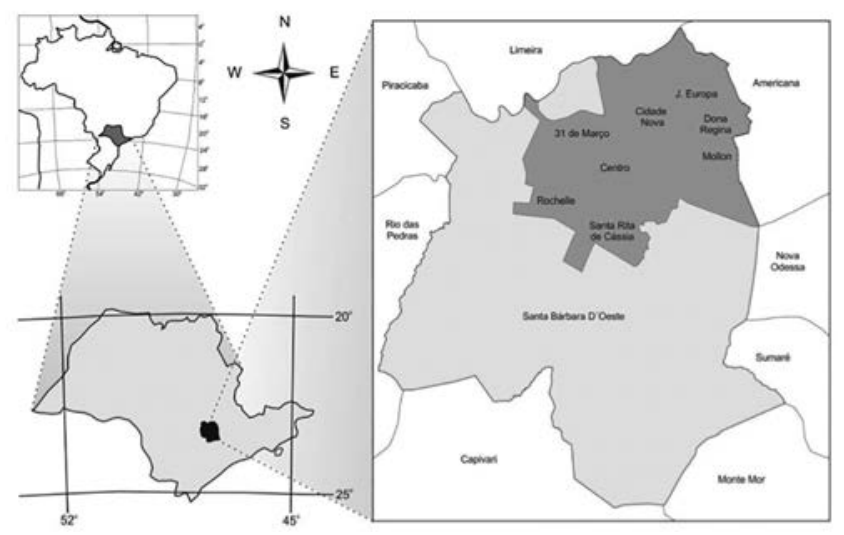

Figure 1. The sampling area located in the Santa Bárbara d'Oeste Municipality in the Atlantic Forest biome, São Paulo state, Brazil. 
cycles and time of occurrence. The wavelet statistics yield a scalegram, which is a graphic representation of wavelet coefficients, showing the cyclical behaviour of variables (Torrence and Compo, 1998) and a global wavelet spectrum. The results of the wavelet analyses were employed to assess the statistical correlation between the surface temperature and spatial distribution of $A e$. aegypti. For the analyses we chose dates when the number of larval habitats positive for Ae. aegypti was high. We employed Landsat5 satellite images available at National Institute of Spatial Research (http://www.dgi.inpe.br/CDSR/). Images were selected for the larval collection date. Four surface temperature maps for the period February 2004-February 2006 were generated for Santa Bárbara d'Oeste. The Idrisi Geographical Information System (Eastman, 1999) was employed to estimate the surface temperature using the SEBAL algorithm, based on Steinke et al. (2010) and Moreira et al. (2011). The apparent temperatures were transformed from the digital signal of the satellite into radiance $\left(\mathrm{w} / \mathrm{m}^{2} . \mathrm{sr} . \mu \mathrm{m}\right)$. The digital number of each pixel image (resolution of $120 \mathrm{~m}$ ) was converted into monochromatic spectral radiance. After adjusting the radiance, the atmospheric noise was corrected and thus the planetary and the surface albedo. Emissivity was calculated using Planck's inverted function (https://ncc.nesdis.noaa.gov/data/ planck.html) that allows the use of blackbody temperatures $(K)$. Surface temperature (Ts) was then calculated using the parameters obtained in the spectral radiance of the thermal band and emissivity according to the following function:

$$
T_{s}=\frac{K_{2}}{\ln \left(\frac{\epsilon_{N B} K_{1}}{L_{\lambda, 6}}+1\right)}
$$

where $K_{1}=607.76 \mathrm{Wn}-22 \mathrm{r}^{-1} \mu \mathrm{m}^{-1}$ and $K_{2}=1260.56$; these are calibration constants of Landsat-5's thermal band.

Statistical spatial correlation between surface temperature and localities with the highest probability of standing larval habitats of Ae. aegypti was assessed using the inhomogeneous $\mathrm{K}$ function model. This model can be used to verify spatial correlations in point patterns and determine the impact of UHIs on the abundance of Ae. aegypti larval habitats. The kernel ratio for temperature, with a covariate for point intensity, generated a smoothed surface, which estimates the value of the larval habitat rate for an area.

Statistical tests were carried out to determine the potential correlation between the local point intensity of larval habitats of $\mathrm{Ae}$. aegypti and São Paulo State Social Vulnerability Index for Santa Barbara d'Oeste (SEADE, 2010). For correlation analysis we employed the spatial and temporal distribution of geo-referenced larval habitats determined by the wavelet analysis. These data were homogenised by the area of the sectors of occurrence determined according to the social vulnerability index levels. Further, the same procedure adopted for the spatial analysis of surface temperature was employed to assess the importance of social vulnerability on the abundance of larval habitats. All analyses were performed using SPATSTAT package in R software (Baddeley et al., 2015).

\section{Results}

The wavelet analysis of larval habitat occurrence (Figure 2) showed a clear annual periodicity of about 365 days (red colour in the figure). This periodicity is only detectable during the months of
December to March of each year, a period that coincides with hotter and wetter summer months when larval habitat occurrence is greatest (Figure 3). No other signal of periodicity is detectable in the time series.

Monthly periodicity showed a sinusoidal pattern (Figure 3) with the largest number of habitats occurring in the months with higher temperatures (January-April); the number of larval habitats recorded during the field collections had a peak of 92, 93 and 75 on February 6th 2004, February 3rd 2005 and February 17th, 2006, respectively, while numbers dramatically declined during winter, reaching zero for some winter days in both 2004 and 2005.

When assessing the correlation between larval habitats and UHIs, we used the temperatures registered on 4th February and 14th August 2004 and 14th February and 22nd June 2005. The surface temperature varied from 15 to $31^{\circ} \mathrm{C}$ within the urban area of Santa Bárbara d'Oeste (Figure 4).

The charts drawn with the help of the Landsat-5 satellite images showed that a warm front reached the municipality at the beginning of February 2004 reducing the cloud cover and thus the probability of precipitation, and thus creating conditions for UHIs. In the first fortnight of August 2004, a high-pressure area was recorded, resulting from a polar anticyclone and Atlantic polar air mass that caused increased air moisture in the atmosphere and humidity on the ground, leading to reduced cloud cover and the creation of UHIs. At the end of February 2005, a high-pressure system caused by a tropicalized polar air mass reduced ground and

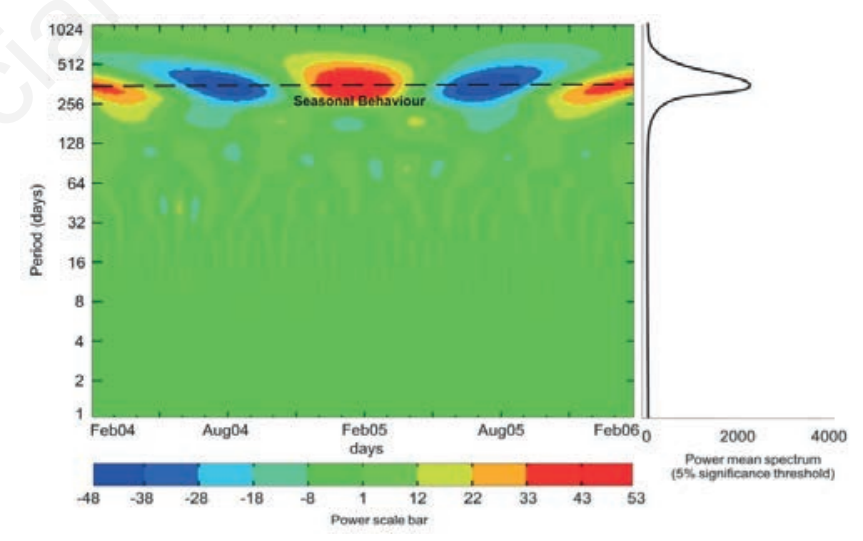

Figure 2. Wavelet analyses of larval habitat frequency per week sampled in Santa Bárbara d'Oeste, Sáo Paulo, Brazil from January 2004 to February 2006. The wavelet period is given in days on a log scale (vertical axis). The colour code for power ranges from low (dark blue) to high values (red).

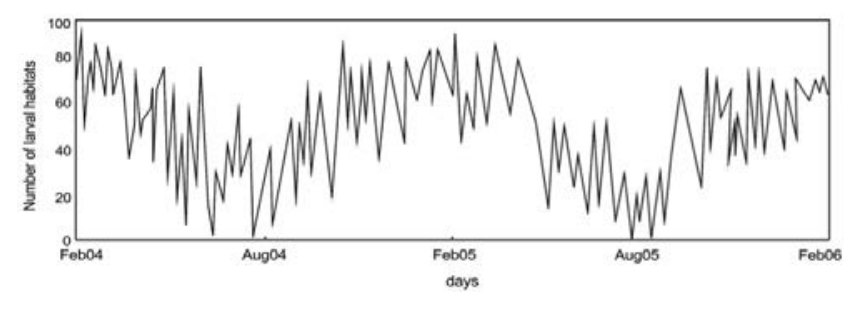

Figure 3. Temporal distribution of larval habitats occupied by Aedes aegypti in Santa Bárbara d'Oeste, São Paulo, Brazil from January 2004 to February 2006. 
atmospheric humidity, thus intensifying the formation of heat islands. The overall conditions observed in the second fortnight of August 2005, with the presence of a high-pressure system caused by a polar anticyclone and cold Atlantic air, also permitted the development of UHIs. The results of inhomogeneous $K$ function model analysis (Figure 5) showed a spatial correlation between the temperature and frequency of occurrence of larval habitats (Zscore 4.99; Z-score critical with $2.59,95 \%$ of significance). As such, the areas with the highest risk of occurrence of Ae. aegypti habitats were identified in the neighbourhoods of Jardim Europa and Mollon.

The distribution of the larval habitats in relation to the São Paulo State Social Vulnerability Index (Figure 6) showed that the highest frequency of larval habitats occurs in the eastern part of the city, in the conurbation of Santa Bárbara d'Oeste and the Americana municipality. Another area presenting a high number of

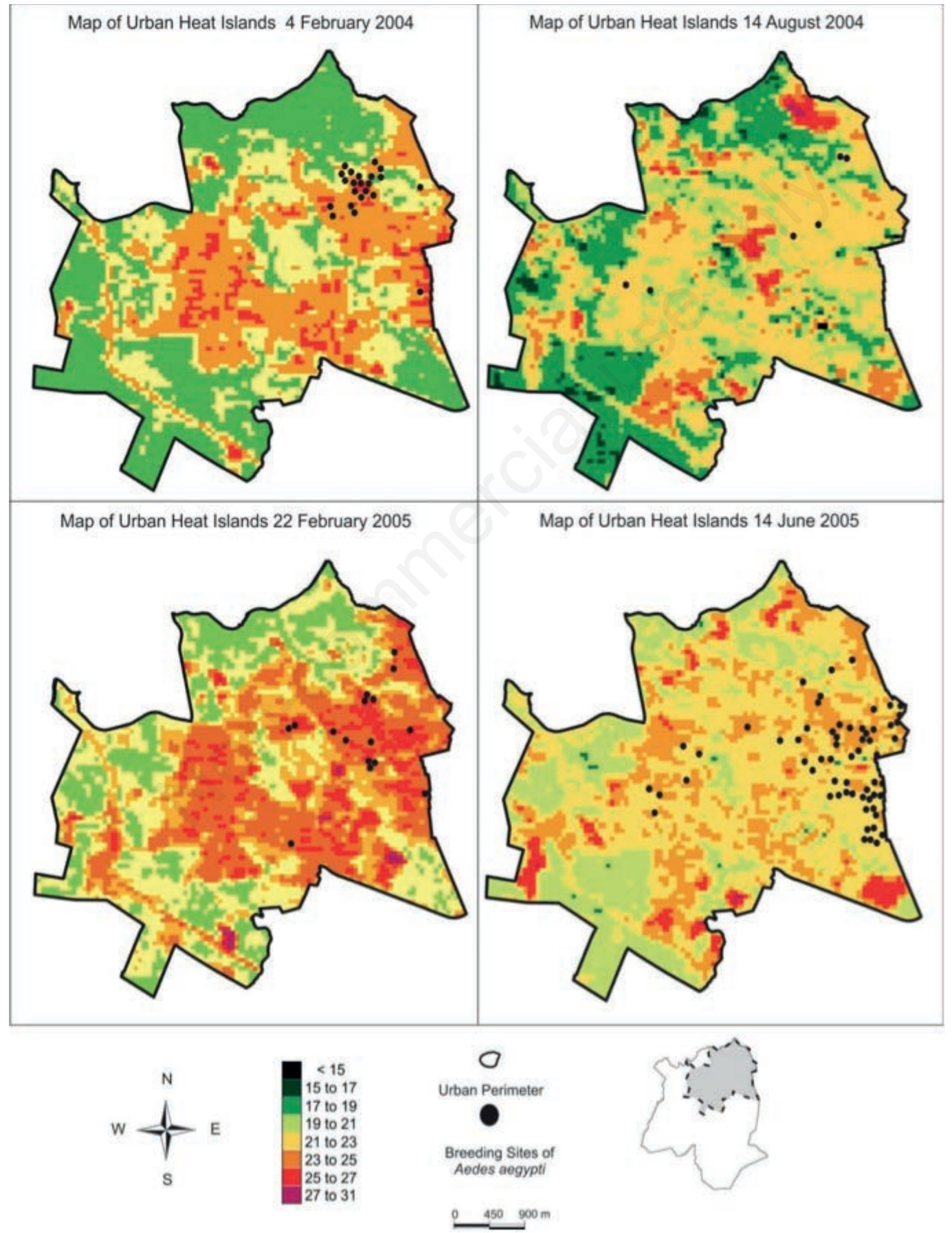

Figure 4. Map of surface temperature with the habitats of Aedes aegypti in the urban area of Santa Bárbara d'Oeste, São Paulo, Brazil from February 2004 to February 2006. 
larval habitats was situated in the central part of the Santa Barbara d'Oeste, but it was lower than in the region of conurbation with the municipality of Americana. The inhomogeneous point pattern analysis (Figure 7) showed spatial autocorrelation (Z-score 9.11, Z-score critical with $2.58,95 \%$ of significance) between larval habitat occurrence and level of social vulnerability. The areas with the highest risk of Ae. aegypti larval habitat were those of high social vulnerability, located in Jardim Europa, Dona Regina and Mollon.

The existence of larval habitats in the areas of high social vulnerability was likely due to these areas having greater numbers of potential larval breeding substrates, a wide variety of which were found across the study area (Figure 8).

\section{Discussion}

UHIs can influence the life cycle of Ae. aegypti by providing conditions favourable with respect to this mosquito's occurrence and development, even when surface temperatures are adverse (Misslin et al., 2016). In a preliminary study on this subject in the city of Santa Bárbara d'Oeste, São Paulo, Azevedo et al. (2013) found breeding sites of Ae. aegypti at air temperatures that were lower than the species survival threshold. Similar results were found in recent studies carried out in the city of São Paulo (Araujo et al., 2015) and in Thailand (Chaves et al., 2014) further supporting the hypothesis that the occurrence of UHIs is favourable for the proliferation of Ae. aegypti.

The results of the current study in the city of Santa Bárbara d'Oeste demonstrated that, even when temperature conditions were adverse to the occurrence and development of Ae. aegypti, UHI-related oscillations in microclimates were responsible for alterations in the usual pattern of mosquito dispersal and activity. Temperatures between 20 and $31^{\circ} \mathrm{C}$ can increase the metabolic rate of the mosquito, shorten the duration of period of larval development and optimise foraging and egg-laying behaviour leading to increased mosquito abundance when larval habitats are available (Scott et al., 2000; Araujo et al., 2015; Misslin et al., 2016; Murdock et al., 2017). In addition, high temperature may have a positive impact on vector competence. Results of experiments performed under laboratory conditions have demonstrated that great oscillations in temperature can diminish the viral load of mosquitoes (Watts et al., 1987; Turell and Lundström, 1990). Daily temperature range can also impact vector competence and the capacity of a mosquito species to transmit the dengue virus, as shown by Lambrechts et al. (2011) in experiments using Ae. aegypti and two different dengue serotypes.

UHIs can play an important role in the dynamics of dengue virus transmission because this phenomenon may maintain a more stable surface temperature, narrow daily temperature fluctuations
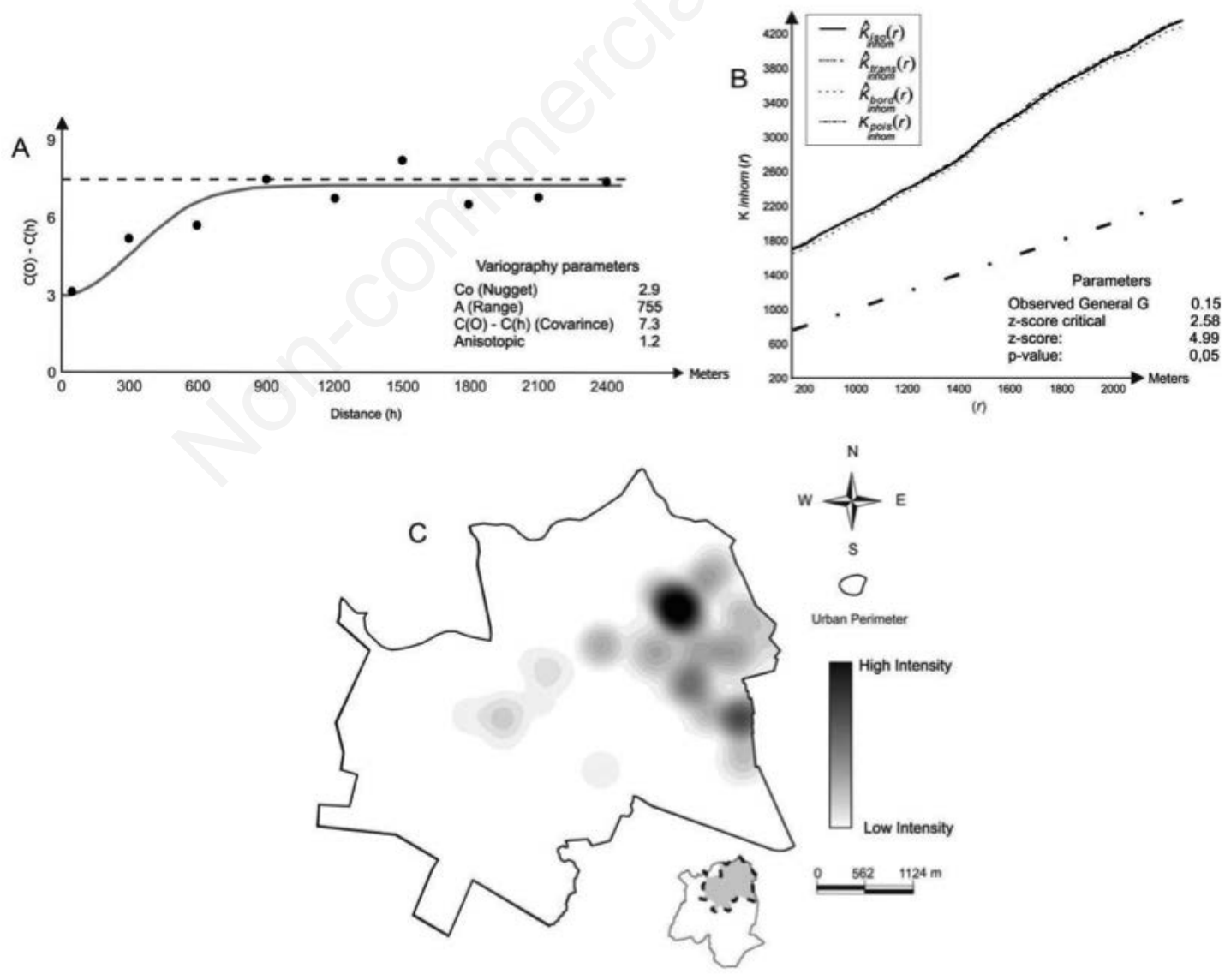

Figure 5. Inhomogeneous spatial point pattern analysis of Aedes aegypti larval habitat occurrences and surface temperatures in Santa Bárbara d'Oeste, São Paulo, Brazil from February 2004 to February 2006. 
and maintain transmission even during the coldest months of the year (Misslin et al., 2016). In this context, UHIs can be used as an abiotic indicator of the risk of dengue virus transmission by mosquitoes. In addition, it can help describe the heterogeneity of dengue distribution in areas where the mosquito vector is present, but where disease transmission is absent, due to, for example, inadequate temperatures for conservation of the circulation of the virus.

Socioeconomic factors have been shown to play a significant role in supporting Ae. aegypti reproductive rates (Reiter, 2014). According to Kuno (1995), social factors that influence the occurrence of larval habitats depend on two distinct pillars. The first is human community behaviour, which is related to factors such as education, income, occupation and population density in an area. The second is the condition of human dwellings, including sanitation of the surrounding environment. Urban areas with bad sanitary conditions, especially in areas with little or no service for recycling waste materials, tend to create larval habitats for Ae. aegypti (Souza-Santos and Carvalho, 2000; Ferreira and Chiaravalloti Neto, 2007; Scandar et al., 2010; Teixeira and Cruz, 2011; Tipayamongkholgul and Lisakulruk, 2011). Studies carried out in Jeddah, Saudi Arabia (Misslin et al., 2016) and Delhi, India (Khormi and Kumar, 2012) found the presence of Ae. aegypti larval habitats in areas of high social vulnerability, which tend to have a high human population density (Chang et al., 1971; Anno et al., 2015), poor sanitary conditions and precarious or absent waste recycling services, factors that also favour larval habitat abundance and high mosquito population density (Huang et al., 2011; Araujo et al., 2015; Misslin et al., 2016). In line with this, we found that in Santa Barbara d'Oeste the incidence of larval habitats was high-

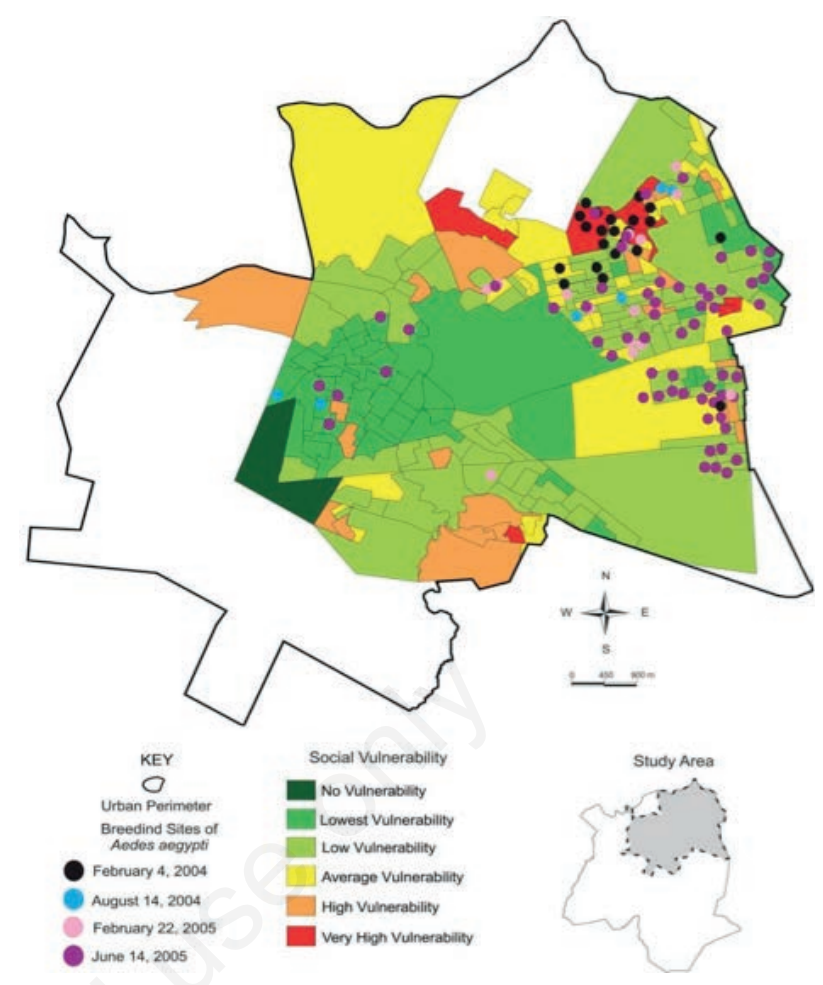

Figure 6. Map of Aedes aegypti larval habitats and the social vulnerability index in the urban area of Santa Bárbara d'Oeste, São Paulo, Brazil from February 2004 to February 2006.
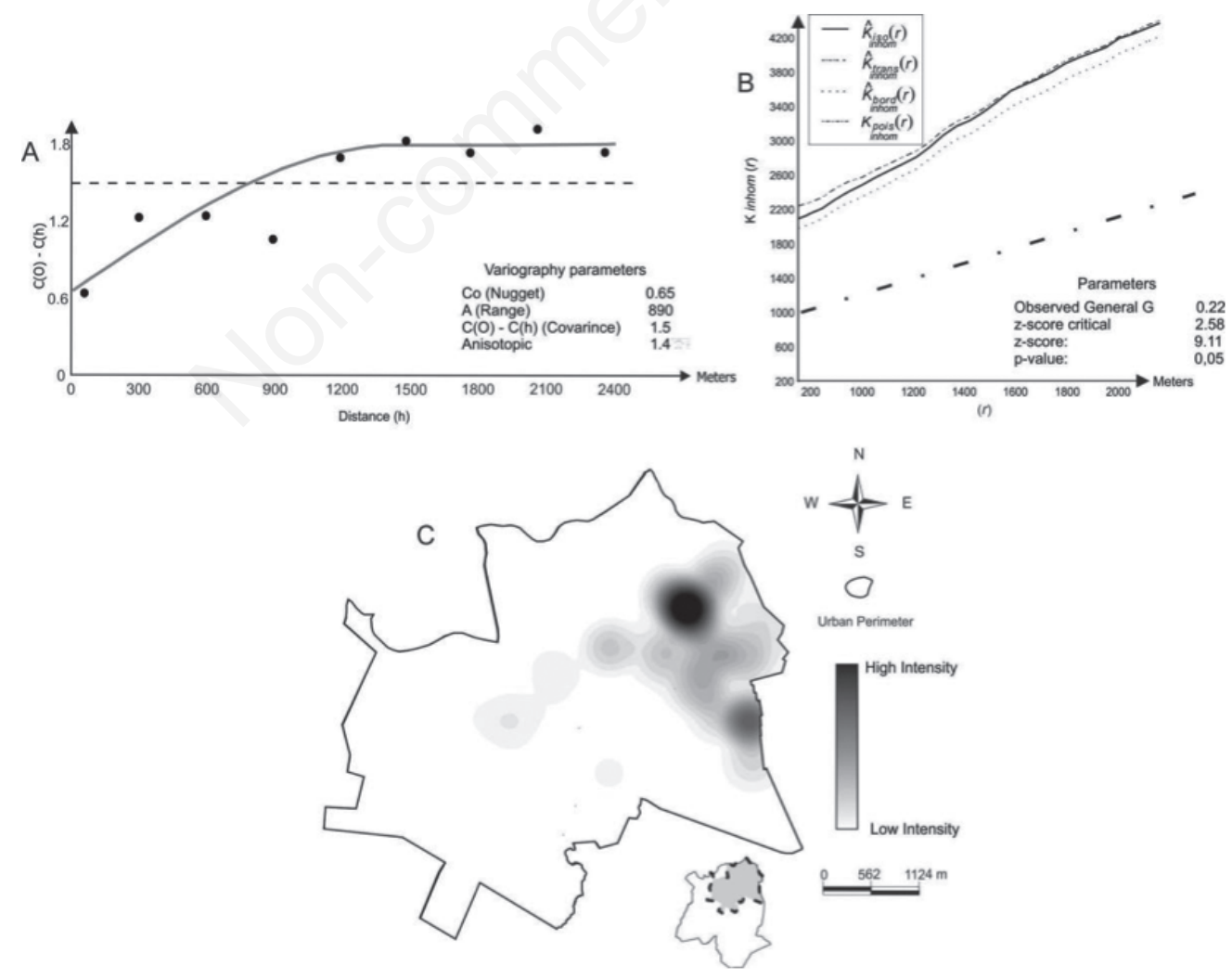

Figure 7. Inhomogeneous spatial point pattern analysis of Aedes aegypti larval habitat density and São Paulo State Social Vulnerability Index in Santa Bárbara d'Oeste, São Paulo, Brazil from February 2004 to February 2006. 
er in areas of high social vulnerability, such as Jardim Europa, Dona Regina, and Mollon.

Taking all results together, our findings highlight the importance of a robust and sustainable surveillance and vector control programme throughout the year. The success of dengue control in urban areas will demand the implementation of social programmes designed to increase the quality of life, education and income of socially vulnerable communities. Furthermore, a sustainable vector control programme will require environmental management and the development of education programmes that will promote the participation of local communities (Piovezan et al., 2014). In addition, the development of urban parks with tree plantations would provide shade to help diminish the occurrence of UHIs, the presence of mosquito larval habitats and the risk of dengue epidemics (Araujo et al., 2015). In our study, the statistical correlation analysis between larval habitat presence and both the occurrence of UHIs and the social vulnerability index helps to explain the spatial and temporal distribution and abundance of Ae. aegypti mosquitoes in urban areas. This information can be important in delineating vector control programmes, while also emphasizing the need for continuous surveillance activities throughout the year, including periods when dengue is less intense. This is particularly relevant given that during these periods both mosquito control programmes and the local communities may interrupt or diminish control measures focusing on the reduction of Ae. aegypti larval habitats.

In dengue endemic countries, temperature and precipitation during winter months may constrain mosquito vector populations and viral development to such a degree as to eliminate or control viral transmission. The occurrence of UHIs, however, provides temperature conditions suitable for maintaining dengue virus transmission at low levels, potentially allowing the virus to circulate unnoticed, and thus unregistered, by surveillance programmes.

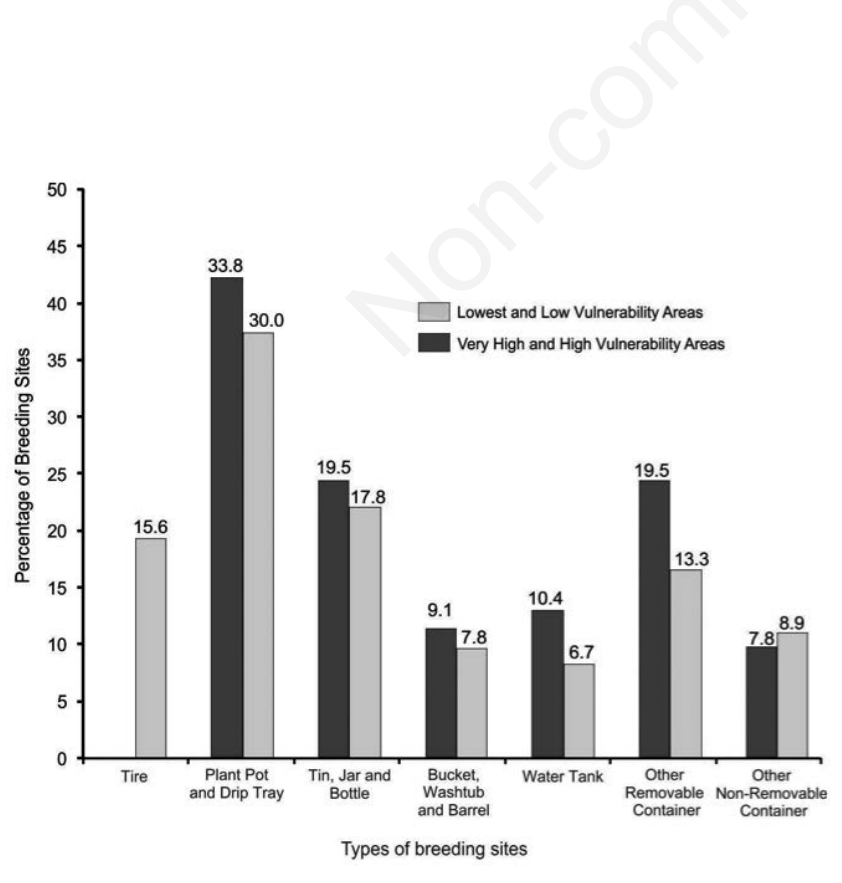

Figure 8. Percentage of Aedes aegypti in different larval habitats located in areas of low and high social vulnerability in Santa Bárbara d'Oeste, São Paulo, Brazil, February 2004 to February 2006.
Maintaining transmission in this way can have the effect of intensifying transmission in more favourable seasons, for example during the summer when the weather conditions better support both mosquito populations and virus development.

\section{Conclusions}

The wavelet analysis in vector-borne diseases was used to extract information from a time series of field collections focusing on the larval habitats of Ae. aegypti. Our analysis demonstrates the cyclical occurrence of larval habitats, and their dependence on both local weather events and levels of social vulnerability, which can be useful to delineate vector surveillance and control programs. High social vulnerability is correlated with an increase in the number of Ae. aegypti larval habitats because of poor or lacking sanitary conditions. The absence or discontinuity of waste recycling programmes and fresh water distribution results in increased use of artificial containers, which are often left with some water inside and can therefore represent larval habitats for urban populations of vector mosquitoes. In addition, the occurrence of UHIs favour the presence of Ae. aegypti in the urban landscape. In conclusion, the findings reported here may also be useful for management strategies in other urban areas with similar ecological conditions and levels of social vulnerability where urban areas favourable for Ae. aegypti can be identified and the circulation of the dengue virus offset.

Susceptible urban areas can be targeted for more intensive and specific mosquito control measures, and for education programmes focused on local community involvement. The participation of local communities in the control program would guarantee the sustainability of the programme that needs to be robust to avoid any negative impact caused by political and economical interferences. Finally, a sustainable vector control programme demands the implementation of measures that eliminate the extreme poverty that is associated with high social vulnerability and increased exposure to vector-borne diseases. As largely discussed in the published literature, extreme poverty is a determinant of the dynamics of vector-borne transmission and its elimination is essential for reaching sustainable global development (WHO, 2017).

\section{References}

Anno S, Imaoka K, Igarashi T, Sivaganesh S, Kannathasan S, Kumaran V, Surendran SN, 2015. Space-time clustering characteristics of dengue based on ecological, socio-economic and demographic factors in northern Sri Lanka. Geospat Health 10:215-22.

Araujo RV, Albertini MR, Costa-da-Silva AL, Suesdek L, Franceschi NCS, Bastos NM, Katz G, Cardoso VA, Castro BC, Capurro ML, Allegro VLA, 2015. São Paulo urban heat islands have a higher incidence of dengue than other urban areas. Braz J Infect Dis 9:146-55.

Azevedo TS, André IRN, Bastos VSB, Piovezan R, Von Zuben CJ, Tavares AC, Ilhas de calor e Aedes aegypti: um estudo preliminar para a cidade de Santa Bárbara d'Oeste, SP-BRA, utilizando sensoriamento remoto. In: Azevedo TS, André IRN, Tavares AC, Souza JG, eds. Geografia da Saúde: experiências do grupo de pesquisas sobre desastres (NUPED) da UNESP, 
Rio Claro, São Paulo, Brasil. Herstellung: Novas Edições Acadêmicas; 2013. pp 19-33.

Baddeley A, Rubak E, Turner R, Spatial Point Patterns: Methodology and applications with R. London: Chapman \& Hall/CRC Interdisciplinary Statistics; 2015.

Barcellos C, Lowe R, 2014. Expansion of the dengue transmission area in Brazil: the role of climate and cities. Trop Med Int Health 19:159-68.

Bhatt S, Gething PW, Brady OJ, Messina, JP, Farlow AW, Moyes CL, Drake JM, Brownstein JS, Hoen AG, Sankoh O, Myers MF, George DB, Jaenisch T, Wint T, William GR, Simmons CP, Scott TW, Farrar JJ, Hay SI, 2013. The global distribution and burden of dengue. Nature 496:504-07.

Braga IA, Valle D, 2007. Aedes aegypti: histórico do controle no Brasil. Epidemiol Serv Saude 2:113-18.

Cardoso CW, Kikuti M, Prates AP, Paploski IA, Tauro LB, Silva MM, Santana P, Rego MF, Reis MG, Kitron U, Ribeiro GS, 2017. Unrecognized emergence of Chikungunya Virus during a Zika Virus outbreak in Salvador, Brazil. PLoS Negl Trop Dis 11:e005334.

Cazelles B, Chavez M, Magny GC, Guégan JF, Hales S, 2007. Time-dependent spectral analysis of epidemiological timeseries with wavelets. J R Soc Interface. 15:625-36.

CEPAGRI, 2013. Centro de Pesquisas Meteorológicas e Climáticas Aplicadas à Agricultura. Clima dos Municípios Paulistas: Campinas. Available from: http://www.cpa.unicamp.br/outrasinformacoes/clima_muni_494.html. Accessed: August 2015.

Chang YC, Chan KL, Ho BC, 1971. Aedes aegypti (L.) and Aedes albopictus (Skuse) in Singapore City. 1. Distribution and density. Bull World Health Organ 44: 617-27.

Chang AY, Fuller DO, Carrasquillo O, Beier JC, 2014. Social justice, climate change, and dengue. Health Hum Rights 16:93104.

Chaves LF, Scott TW, Morrison AC, Takada T, 2014. Hot temperatures can force delayed mosquito outbreaks via sequential changes in Aedes aegypti demographic parameters in autocorrelated environments. Acta Trop 129:15-24.

Chowell G, Cazelles B, Broutin H, Munayco CV, 2011. The influence of geographic and climate factors on the timing of dengue epidemics in Perú, 1994-2008. BMC Infect Dis 11:164.

Costa F, Carvalho-Pereira T, Begon M, Riley L, Childs J, 2017. Zoonotic and vector-borne diseases in urban slums: opportunities for intervention. Trends in Parasitol 33:660-2.

Cuong HQ, Hien NT, Duong TN, Phong TV, Cam NN, Farrar J, Nam VS, Thai KTD, Horby P, 2011. Quantifying the emergence of dengue in Hanoi, Vietnam: 1998-2009. PLoS Negl Trop Dis 5:e1322.

Daubechies I, 1988. Orthonormal bases of compactly supported wavelets. Commun Pure Appl Math 41:909-96.

Eastman JR, 1999. IDRISI 32 for Windows-User's guide.v. 1 and 2. Massachusetts: Clark University.

Faria NR, Quick J, Claro IM, Thézé J, de Jesus JG, Giovanetti M, Kraemer MUG, Hill SC, Black A, da Costa AC, Franco LC, Silva SP, Wu CH, Raghwani J, Cauchemez S, du Plessis L, Verotti MP, de Oliveira WK, Carmo EH, Coelho GE, Santelli ACFS, Vinhal LC, Henriques CM, Simpson JT, Loose M, Andersen KG, Grubaugh ND, Somasekar S, Chiu CY, MuñozMedina JE, Gonzalez-Bonilla CR, Arias CF, Lewis-Ximenez LL, Baylis SA, Chieppe AO, Aguiar SF, Fernandes CA, Lemos PS, Nascimento BLS, Monteiro HAO, Siqueira IC, de Queiroz
MG, de Souza TR, Bezerra JF, Lemos MR, Pereira GF, Loudal D, Moura LC, Dhalia R, França RF, Magalhães T, Marques Jr ET, Jaenisch T, Wallau GL, de Lima MC, Nascimento V, de Cerqueira EM, de Lima MM, Mascarenhas DL, Neto JPM, Levin AS, Tozetto-Mendoza TR, Fonseca SN, Mendes-Correa MC, Milagres FP, Segurado A, Holmes EC, Rambaut A, Bedford T, Nunes MRT, Sabino EC, Alcantara LCJ, Loman NJ, Pybus OG, 2017. Establishment and cryptic transmission of Zika virus in Brazil and the Americas. Nature 546:406-10.

Ferreira AC, Chiaravalloti Neto F, 2007. Infestação de área urbana por Aedes aegypti e relação com níveis socioeconômicos. Rev Saude Publica 41:915-22.

Forattini OP, Culicidologia médica. v. 2. Sao Paulo: Edusp; 2002.

Freitas ARR, Angerami RN, Zuben APBV, Donalisio MR, 2016. Introduction and transmission of Zika virus in Brazil: new challenges for the Americas. Rev Inst Med Trop Sao Paulo 58:24.

Gubler DJ, 1998. Resurgent vector-borne diseases as a global health problem. Emerg Infect Dis 4:442-50.

Guzman MG, Harris E, 2015. Dengue. Lancet 385:453-65.

Haughter G, Hunter C, 1994. Sustainable cities. London: J. Kingsley Publishers.

Huang G, Zhou W, Cadenasso ML, 2011. Is everyone hot in the city? Spatial pattern of land surface temperatures, land cover and neighbourhood socioeconomic characteristics in Baltimore, MD. J Environ Manage. 92:1753-9.

Jentes ES, Poumerol G, Gershman MD, Hill DR, Lemarchand J, Lewis RF, Staples JE, Tomori O, Wilder-Smith A, Monath TP, 2011. The revised global yellow fever risk map and recommendations for vaccination, 2010: consensus of the informal WHO working group on geographic risk for yellow fever. Lancet Infect Dis 11:622-32.

Johansson MA, Cummings DAT, Glass G, 2009. Multiyear climate variability and dengue - El Niño Southern Oscillation, weather, and dengue incidence in Puerto Rico, Mexico, and Thailand: a longitudinal data analysis. PLoS Med 6:e1000168.

Khormi HM, Kumar L, 2012. Assessing the risk for dengue fever based on socioeconomic and environmental variables in a geographical information system environment. Geospat Health 2:171-6.

Knapp S, Winter M, Klotz S, 2017. Increasing species richness but decreasing phylogenetic richness and divergence over a 320year period of urbanization. J Appl Ecol 54:1152-60.

Kraemer MUG, Sinka ME, Duda KA, Mylne AQN, Shearer FM, Barker CM, Moore CG, Carvalho RG, Coelho GE, Bortel WV, Hendrick G, Schaffner F, Elyaza IRF, Teng H, Brady OJ, Messina JP, Pigott DM, Scott TW, Smith DL, Wint WGR, Golding N, Hay SI, 2015. The global distribution of the arbovirus vectors Aedes aegypti and Ae. albopictus. eLife 4:e08347.

Kuno G, 1995. Review of the factors modulating dengue transmission. Epidemiol Rev 17:321-35.

Lafferty KD, 2009. The ecology of climate change and infectious diseases. Ecology 4:888-900.

Lambrechts L, Paaijmans KP, Fansiri T, Carrington LB, Kramer LD, Thomas MB, Scott, TW, 2011. Impact of daily temperature fluctuations on dengue virus transmission by Aedes aegypti. Proc Natl Acad Sci USA 108:7460-5.

Landsberg HE, 1981. The urban climate. New York, NY: Academic Press.

Leparc-Goffart I, Nougairede A, Cassadou S, Prat C, Lamballerie 
X, 2014. Chikungunya in the Americas. Lancet 383:514.

McKinney ML, 2008. Effects of urbanization on species richness: A review of plants and animals. Urban Ecosyst 11:161-76.

Meineke EK, Dunn RR, Sexton JO, Frank SD, 2013. Urban warming drives insect pest abundance on street trees. PLoS One 8:e59687.

Misslin R, Telle O, Daudé E, Vaguet A, Paul RE, 2016. Urban climate versus global climate change-what makes the difference for dengue? Ann NY Acad Sci 1382:56-72.

Mohajerani A, Bakaric J, Jeffrey-Bailey T, 2017. The urban heat island effect, its causes, and mitigation, with reference to the thermal properties of asphalt concrete. J Environ Manage 197:522-38.

Moreira EBM, Nóbrega RS, Silva BB, 2011. Estimativa do saldo de radiação instantânea na cidade do Recife, através de imagens do satélite Landsat 5 TM. Rev Bras Geog Fis 3:589-601.

Murdock CC, Evans MV, McClanahan TD, Mazgowicz L, Tesla B, 2017. Fine-scale variation in microclimate across an urban landscape shapes variation in mosquito population dynamics and the potential of Aedes albopictus to transmit arboviral disease. PLoS Negl Trop Dis 11:e0005640.

Nagao Y, Koelle K, 2008. Decreases in dengue transmission may act to increase the incidence of dengue hemorrhagic fever. Proc Natl Acad Sci USA 105:2238-43.

Naish S, Dale P, Mackenzie JS, Mcbride J, Mengersen K, Tong S, 2014. Climate change and dengue: a critical and systematic review of quantitative modeling approaches. BMC Infect Dis $14: 167$.

Oke TR, 1995. The heat island of the urban boundary layer: characteristics, causes and effects. In: Cermak JE, Davenport AG, Plate, EJ, Viegas DX, eds. Wind climate in cities. Kluwer Academic Publishers. pp 81-107.

Piovezan R, Azevedo TS, Von Zuben CJ, 2012. Spatial evaluation of larvae of Culicidae (Diptera) from different breeding sites: application of a geospatial method and implications for vector control. Rev Bras Entomol 56:368-76.

Piovezan R, Azevedo TS, Acorinthe JPO, Polizelli N, Visockas A, Canteiro CL, Von Zuben CJ, 2014. Perfil epidemiológico e análise espacial do risco da dengue da área urbana de Santa Bárbara d'Oeste - SP, durante o período de 1995 a 2010. Geografia 39:525-39.

Possas C, Martins RM, Oliveira RL, Homma A. 2018. Urgent call for action: avoiding spread and re-urbanisation of yellow fever in Brazil. Mem Inst Oswaldo Cruz 113:1-2.

Reiter P, 2010. Surveillance and control of urban dengue vector. In: Gubler DJ, Ooi E, Vasudevan S, Scandar SAS, Vieira P, Cardoso Junior RP, Silva RA, Papa M, Sallum, MAM. Dengue em São José do Rio Preto, Estado de São Paulo, Brasil, 1990 a 2005: fatores entomológicos, ambientais e socioeconômicos. Bepa 7:4-16.

Scott TW, Amerasinghe PH, Morrison AC, Lorenz LH, Clark GG, Strickman D, Kittayapong P, Edman JD, 2000. Longitudinal studies of Aedes aegypti (Diptera: Culicidae) in Thailand and Puerto Rico: Blood feeding frequency. J Med Entomol 37:89101.

SEADE, 2010. Fundação Sistema Estadual de Analise de Dados. SEADE Índice Paulista de Vulnerabilidade Social (IPVS)
2010. São Paulo: Governo do Estado de São Paulo. Available from: http://www.seade.gov.br/. Accessed: May 2013.

Simmons CP, Farrar JJ, Chau NVV, Wills B, 2012. Dengue. N Engl J Med 366:1423-32.

Souza-Santos R, Carvalho MS, 2000. Análise da distribuição espacial de larvas de Aedes aegypti e do dengue na Ilha do Governador, Rio de Janeiro, Brasil. Cad Saude Publica 16:3142.

Steinke VA, Steinke ET, Saito, CH, 2010. Estimativa da temperatura de superfície em áreas urbanas em processo de consolidação: reflexões e experimento em Planaltina-DF. Rev Bras Climatol 6:37-56.

Teixeira TRA, Cruz, OG, 2011. Spatial modeling of dengue and soci-environmental indicators in the city of Rio de Janeiro, Brazil. Cad Saude Publica 27:591-602.

Thai KTD, Anders, KL, 2011. The role of climate variability and change in the transmission dynamics and geographic distribution of dengue. Exp Biol Med 236:944-54.

Tipayamongkholgul M, Lisakulruk S, 2011. Socio-geographical factors in vulnerability to dengue in Thai villages: a spatial regression analysis. Geospat Health 2:191-8.

Torrence C, Compo GP, 1998. A practical guide to wavelet analysis. BAM S 79:61-78.

Turell MJ, Lundström JM, 1990. Effect of environmental temperature on the vector competence of Aedes aegypti and Ae. taeniorhynchus for ockelbo virus. Am J Trop Med Hyg 43:54350.

Tyson PD, du Toit WJF, Fuggle RF, 1972. Temperature structure above cities: review and preliminary findings from the Johannesburg urban heat island project. Atmos Environ 6:53342.

Vega-Rúa A, Zouache K, Girod R, Failloux AB, Lourenço-deOliveira R, 2014. High level of vector competence of Aedes aegypti and Aedes albopictus from ten American countries as a crucial factor in the spread of Chikungunya virus. J Virol 88:6294-06.

Watts D, Burke DS, Harrison BA, Whitmire RE, Nisalak A, 1987. Effect of temperature on the vector efficiency of Aedes aegypti for dengue 2 virus. Am J Trop Med Hyg 36:143-52.

Weng H, Lau KM, 1994. Wavelet, period doubling, and time-frequency localization with application to organization of convection over the tropical western Pacific. J Atmos Sci 51:2523-41.

Xu L, Stige LC, Chan KS, Zhou J, Yang J, Sang S, Wang M, Yang Z, Yan Z, Jiang T, Lu L, Yue Y, Liu X, Lin H, Xu J, Liu Q, Stenseth NC, 2017. Climate variation drives dengue dynamics. Proc Natl Acad Sci USA 114:113-8.

YangHM, 2009, Assessing the effects of temperature on the population of Aedes aegypti, the vector of dengue. Epidemiol Infect. 137:1188-202.

WHO. Global vector control response 2017-2030. Geneva: World Health Organization; 2017.

Zanluca C, Melo VCA, Mosimann ALP, Santos GIV, Santos CND, Luz K, 2015. First report of autochthonous transmission of Zika virus in Brazil. Mem Inst Oswaldo Cruz 110:569-72. 